\title{
The Influence of Principal's Leadership and Teacher's Competence toward Teacher's Performance in Indonesia
}

\author{
Suratman \\ SMP Negeri 5 Tungkal Jaya, Indonesia \\ e-mail: ratman.oce@gmail.com \\ Yasir Arafat \\ Universitas PGRI Palembang, Indonesia \\ e-mail: yasir_arafat14.yahoo.com \\ Syaiful Eddy \\ Universitas PGRI Palembang, Indonesia \\ e-mail: syaifuleddy@gmail.com \\ Article History: Received on 18 September 2020, Revised on 24 September 2020, \\ Published on 24 September 2020
}

\begin{abstract}
This study determined whether there is an effect of principal leadership and teacher competence on teacher's performance at SMP Negeri 1 Sungai Lilin, either partially or simultaneously. The population of this research is 40 teachers. The technique of collecting data using a questionnaire, with data analysis using multiple linear regression of SPSS 25. The results obtained in this study 1) there is no influence of principal leadership on teacher's performance; 2) there is an effect of teacher's competence on teacher's performance; and 3) simultaneously there is an effect of principal leadership and teacher's competence on teacher's performance. This paper contributes to improve teacher's performance through principal leadership and teacher's competence.
\end{abstract}

Keywords: Principal Leadership, Teacher's Performance, Teacher's Competence, High Quality Education, Secondary School

\section{A. Introduction}

Teachers who have been the only main role in providing scientific education services will gradually be displaced along with the times. In order to remain needed and meaningful in their existence in the classroom, therefore teachers must always be required to innovate and have creativity as needed. As stated by Kristiawan et al (2019); Kristiawan (2015) that to optimize the ability of students, readiness of human resources, develop student character values, digital-based learning facilities and infrastructure, appropriate curricula and policies in education are some of the solutions that need to be done in the world of education.

In other words, the world of education which produces human resources is demanded how to produce human resources who are ready for this development. Human resources have a major role in achieving goals or success and for the continuation of development in modern times. Improving the quality of human resources through education and development must be carried out. As stated in Law Number 20 of 2003 concerning the national education system, 
Article 3 states that educational units are strived for in order to achieve the goals of national education.

The role of a leader is very important in order to make this happen. Because the main element for the effectiveness of a school is the principal. The various types of school programs that have been prepared in a dynamic way by the principal is one of the characteristics of a good principal. As explained by Pianda (2018), the success or progress of a school is strongly influenced by the leadership pattern of the principal. When able to carry out their duties with a full sense of responsibility in their role as a leader, and understanding that the school is an organization consisting of various elements is an indicator of the success of the principal as a leader. As stated by Andang (2014) that in order to maximize the implementation of management, his role as a leader in the world of education with full responsibility, the principal must have a good spirit of professionalism. Then it is also explained by Mataputun (2020) that there are several core dimensions of principal leadership that encourage the sustainable success of a school.

In a school, the principal will set a policy so that the principal, who in other words is a leading leader, is required to improve the quality of his performance by considering work effectiveness (Andriani et al, 2018; Irmayani et al, 2018). In line with that Andang (2014) explains the role of a leader as a decision maker, including (1) entrepreneur, school performance can be improved by the principal, (2) disturbance, handler, pay attention to disturbances that arise, (3) a resource allocator, provide school resources, (4) a negotiator role, able to hold talks with outsiders.

Leadership at SMP Negeri 1 Sungai Lilin in the last four years has occurred three times the change of school principals, with different characters and disciplines. Currently, the head of SMP Negeri 1 Sungai Lilin is led by a leader who was previously the principal of a new school. Personally, the school principal has won achievements as an outstanding teacher at the district and provincial levels, besides being active in writing scientific papers, including being a speaker at the 2019 national physics education seminar in Palembang and a finalist in the 2016 national level Inobel competition.

Another component that affects the success of a school is the teacher, because the teacher's role is very important. The role of the teacher is contained in Article 35 paragraph 1 of Law of the Republic of Indonesia Number 14 of 2005, namely activities starting from planning to evaluating learning, educating or training students, coupled with additional tasks, therefore teachers must have a creative and innovative spirit in their learning. Because teachers are expected to be able to improve the quality of education with a school system, for the sake of creating future Indonesian citizens with life skills, good science and technology mastery and a spirit of character (Sayer et al, 2018; Lian et al, 2020).

To align the teacher's role, a teacher must have competence. As stated in the Law of the Republic of Indonesia Number 14 of 2005 concerning teachers and lecturers, the competencies that teachers need to have include: pedagogical competence, personality competence, social competence, and professional competence obtained through professional education. This competence for teachers is able to foster motivation in carrying out their duties, but this does not happen in the field. Because there are still frequent findings that teachers have not carried out their duties with a full sense of responsibility and professionalism. 
Based on the explanation of Law Number 14 of 2005, the condition of teachers at SMP Negeri 1 Sungai Lilin itself consists of civil servants and honorarium. This means that in terms of competencies that must be possessed, there are competencies that are not possessed by every teacher, namely professional competence, especially when it says professional competence is obtained through professional education, and we need to know that until now there has been no educational institution that has opened such education in general. Legal professional competence is only obtained by teachers who have met the requirements set by the LPMP, through their respective teacher PKB accounts that are synchronized with their respective school dapodic applications.

Teachers of SMP Negeri 1 Sungai Lilin received assistance from the Putera Sampoerna Foundation School Development Outreach's Lighthouse School Program for 3 years. This activity is very supportive of the situation of teachers at SMP Negeri 1 Sungai Lilin who are very diverse in competence and experience. Where civil servant teachers and honorarium appointed by the school to participate in mentoring get the opportunity to improve their competence. The materials given by the LSP to the teachers they accompany are about school management, 21st century learning, fun learning models, and graphic organizers.

Furthermore, success in learning, the role of the teacher is very decisive, so the teacher must have a work ethic, complete teacher competence to carry out their duties, especially those related to carrying out their duties in teaching and learning activities professionally according to teacher professional ethics. As stated by Fathurrochman et al (2019) in his research, the results show that the role of teachers in learning can improve learning outcomes, by showing that there are teachers who are media educators, mediators, facilitators, organizers, initiators, educators, as actors, models and evaluators.

Both companies that provide services as a commodity, as well as education, things that need to be taken seriously are performance (Khasanah et al, 2019). Good performance is needed to do all of that, a good performance must have a factor that affects it. To carry out their duties properly, teacher performance is related to their motivation and competence. Through special coaching both internally and externally, it can provide the competence and motivation that is in a teacher to carry out his duties. Then Pianda (2018) states that the student achievement he gets at school can be an indicator of the success of the teacher in teaching or educating.

Based on the observations from the description, it is necessary to research the problem of the influence of the principal's leadership and teacher competence in maximizing teacher performance at SMP Negeri 1 Sungai Lilin. Furthermore, to find out how much influence the head of SMP Negeri 1 Sungai Lilin has in carrying out his duties as a leader, so that teacher performance can develop. And whether the competence of teachers controlled by teachers is in accordance with Law Number 14 of 2005 concerning Teachers and Lecturers in order to improve their performance as teachers at SMP Negeri 1 Sungai Lilin.

\section{B. Methods}

This research took place at SMP Negeri 1 Sungai Lilin. The main reason for determining the location of this research is because the school is classified as a fairly advanced and good quality school, with a fairly large number of students. In the 2019/2020 school year the total number is 764 students, 351 male students and 413 female students. Theoretically, an advanced and good quality school is characterized by management stability which includes aspects of leadership and managerial skills. The approach in this research is quantitative, data 
collection in the form of numeric is followed by processing the data with a statistical approach then interpreted.

The population in this study were 40 teachers at SMP Negeri 1 Sungai Lilin, Sungai Lilin District, Musi Banyuasin Regency, South Sumatra, with a formation of 20 teachers with civil servant status and 20 honorariums. There are 20 teachers who have been certified. The number of samples in this study were 40 teachers from all teachers at SMP Negeri 1 Sungai Lilin. The instrument used in collecting data in this study was a questionnaire with a circuit scale and a documentation study. The technique used in the data analysis of this research is descriptive statistical techniques.

\section{Results and Discussion}

\section{The Influence of Principal's Leadership towards Teacher's Performance}

After going through data processing and analysis using Linear Regression with the help of SPSS 25 indicated by a positive beta value $(\beta=+0.33)$, with a regression coefficient value of plus $(+)$ it can be said that the principal's leadership $\left(\mathrm{X}_{1}\right)$ has a positive effect on performance teacher. The regression equation is $\mathrm{Y}=1.547+0.330 \mathrm{X}$ which means: 1 ) a constant value of 1.547 which means that if there is no leadership of the principal, the teacher's performance is $1.547,2)$ the value of the principal's leadership regression coefficient is 0.330 which means that every $1 \%$ addition of leadership the principal, the teacher's performance increased by 0.330. The magnitude of the increase in the influence of the principal's leadership on teacher performance based on the calculation of the coefficient of determination obtained an $\mathrm{R}$ square value of $8.8 \%$, in other words that the amount of increase in the principal's leadership on teacher performance is $8.8 \%$.

From the calculation results, the sig value is obtained. of 0.063 , so the significance value is greater than the probability value of 0.05 or $(0.33>0.05)$. With this result, $\mathrm{H}_{0}$ is accepted, meaning that there is no significant effect of the principal's leadership on teacher performance at SMP Negeri 1 Sungai Lilin. When viewed from the t-test results, the t-table value is 2.024 and the $t$-count value is 1.915 , because the $t$-count value is smaller than the $t$ table value, there is no influence of the principal's leadership on teacher performance.

If you look at the results of the questionnaire, the principal's leadership variable is quite satisfying with $67.5 \%$ with high predicate and $32.5 \%$ with moderate predicate. This illustrates that the principal's leadership performance is going well. Thus the insignificance of the principal's leadership on teacher performance there are other factors that cause this to occur. These factors include the frequent changes in leadership that have occurred in the school, in the last 4 years there have been 3 school principals, where each school principal has a different leadership style and policy for each individual. As stated by Andriani et al (2018); Salwa et al (2019), leaders have different efforts and styles in carrying out their duties as leaders.

Another factor is that $85 \%$ of the teacher education qualifications at SMP Negeri 1 Sungai Lilin are linear, and there are $20 \%$ teachers with postgraduate qualifications so that it has an impact as peer-to-peer learning to improve the quality of their performance. As disclosed by Tobari et al (2018) that the peer method can improve test quality or achievement. 
The results of this study are supported by the results of previous research conducted by Kartini et al (2020) which shows that there is no significant effect of principal leadership on teacher performance. This can be influenced by factors related to factors of age, years of service, employment status, given the employment status of dominant teachers as nonpermanent teachers.

Then similar to the results of research conducted by Ridwan and Karna (2018) with the title "The Effect of Principal Leadership, Teacher Competence, and Teacher Compensation on Teacher Performance in SMP Pertiwi" with the results of the study showing that the leadership variable is in the low category, the total leadership influence. by $6.6 \%$. The influence of the principal's leadership on teacher performance is not yet significant, there are several factors causing it, one of which is expressed by Mataputun (2020) that the principal's leadership has not been optimal in carrying out his responsibilities at school, which will result in weakening teacher performance in the learning process. Another factor can be caused by the principal in making policies or decisions as explained by Mataputun (2020) that leaders make decisions quickly, and a high level of optimism affects teacher performance.

\section{The Influence of Teacher's Competence towards Teacher's Performance}

From the results of Linear Regression with the help of SPSS 25, it is indicated by a positive beta value $(\beta=+0.595)$, with a regression coefficient value of plus $(+)$, it can be said that teacher competence has a positive effect on teacher performance. The regression equation is $\mathrm{Y}=0.595+0.914 \mathrm{X}$ which means: 1) a constant value of 0.595 which means that if there is no teacher competence, the teacher's performance is $0.595,2$ ) the principal's leadership regression coefficient value is 0.914 which means that every $1 \%$ addition of teacher competence then the teacher's performance increased by 0.914 . The magnitude of the increase in the influence of teacher competence on teacher performance based on the calculation of the coefficient of determination obtained $\mathrm{R}$ square value of $53.1 \%$, in other words that the amount of increase in teacher competence on teacher performance is $53.1 \%$.

From the calculation results, the sig value is obtained. of 0.00 so that the significance value is smaller than the probability value of 0.05 or $(0.00<0.05)$. With this result, $\mathrm{H}_{0}$ is rejected, meaning that there is a significant effect of teacher competence on teacher performance at SMP Negeri 1 Sungai Lilin. When viewed from the t-test results, the t-table value is 2.024 and the t-count value is 6.561 , because the $\mathrm{t}$-count value is greater than the t-table value, there is an effect of teacher competence on teacher performance.

The results of the $X_{2}$ variable in this study are in line with the results of research conducted by Zubaidah (2016) with the title of his research "The Influence of Principal Leadership and Teacher Competence on Teacher Motivation and Its Implementation on Teacher Performance at SMP Negeri Palembang City" which shows that partially there are positive and significant influence of teacher competence on teacher performance in SMP Negeri Palembang.

These results are in accordance with the opinion expressed by Daryanto (2013) that speaking calmly of teacher competence is talking about the knowledge, skills, and attitudes that a teacher must have and their application in work according to field needs. This means that there is a positive and significant effect of teacher competence on teacher performance at SMP Negeri 1 Sungai Lilin. One of the indicators is good mastery of teacher competence and appropriate placement. This is indicated by the results of filling out the questionnaire getting 
a moderate predicate (susceptible to score $63-81$ ) as much as $55 \%$ and those receiving a moderate predicate (vulnerable value $44-62$ ), namely $45 \%$ or 18 respondents.

With the assistance of SMP Negeri 1 Sungai Lilin from the LPS (Lighthouse School Program), the teachers received training on material knowledge of science, technology, engineering and mathematics, English and teachers were trained to apply international learning practices. This assistance is certainly one of the good factors in achieving the competency of the teachers at SMP Negeri 1 Sungai Lilin.

The role of the principal as a supervisor has been carried out well, with an academic supervision program held once a semester. This supervision activity is certainly an effort from the principal in improving teacher competence. Teacher competencies that can be improved in academic supervision include planning (making learning tools and media), implementation (mastering material, learning methods, assessment), in addition to improving the ability of teachers to carry out active, creative, and effective learning.

\section{The Influence of Principal's Leadership and Teacher's Competence towards Teacher's Performance}

The results of data analysis using Multiple Linear Regression with the help of SPSS 25, the results obtained are a constant value of 0.493 , the principal leadership variable coefficient (X1) of 0.071, and the teacher competency variable coefficient of 0.887 . These results can be interpreted as: 1) A constant of 0.493, stating that if there is no improvement in the principal's leadership pattern $\left(\mathrm{X}_{1}\right)$ and teacher competence $\left(\mathrm{X}_{2}\right)$, the teacher's performance $(\mathrm{Y})$ remains at 0.493 . This shows that there are other variables that can influence it but not in this study; 2) The principal leadership regression coefficient $\left(\mathrm{X}_{1}\right)$ is 0.071 or $7.1 \%$, which means that the projection tendency of changes between the principal's leadership $\left(\mathrm{X}_{1}\right)$ and the teacher performance variable (Y) shows that an increase in the principal's leadership variable is $100 \%$, which results in an increase as well. on the teacher performance variable of $7.1 \%$ with a significant level of 5\%; 3) The regression coefficient value of teacher competence $\left(\mathrm{X}_{2}\right)$ is 0.887 or $88.70 \%$, which means that the projection tendency of changes between teacher competence $\left(\mathrm{X}_{2}\right)$ and teacher performance variables $(\mathrm{Y})$ shows that an increase in the teacher competency variable is $100 \%$ which results in an increase in performance variables. teachers amounted to $88.7 \%$ with a significant level of $5 \%$.

Simultaneously there is a positive and significant influence on principal leadership and teacher competence on teacher performance at SMP Negeri 1 Sungai Lilin. This is indicated by the constant value of 0.493 , b1 of 0.071 , and b2 of 0.887 . as for the sig value. by 0.00 . The magnitude of the influence of principal leadership and teacher competence on teacher performance based on the results of the R Square value of 0.535 means that the influence of principal leadership and teacher competence on teacher performance at SMP Negeri 1 Sungai Lilin together is $53.5 \%$ and the remaining $46.5 \%$ is influenced by other factors that are not this variable.

The results obtained show that there is a direct influence of the principal's leadership by $7.1 \%$, and a direct influence of teacher competence by $88.7 \%$. When viewed from the composition of the influence, it can be seen that the competence of teachers on teacher performance at SMP Negeri 1 Sungai Lilin is more dominant when compared to the leadership of the school principal. This implies that competence has the greatest influence on 
teacher performance, the better the competence of the teacher, the better the teacher's performance.

These results are in line with the results of research conducted by Ridwan and Karna (2018) with the results of their research that the simultaneous influence of principal leadership, teacher competence and teacher compensation has a significant effect on teacher performance at SMP Pertiwi Dayeuhkolot, the total influence of head leadership variables. school, teacher competence and teacher compensation jointly on teacher performance amounting to $67.3 \%$.

The positive and significant influence of principal leadership and teacher competence simultaneously on teacher performance at SMP Negeri 1 Sungai Lilin is directly proportional to the results of the partial test, in which the two independent variables also have a positive effect. This is confirmed by the opinion of Pianda (2018) that the weakening of teacher performance is caused by the leadership role of the principal as the direct superior or the supervisor who holds the key to leadership has not been able to arouse morale towards his subordinates and there are still many teachers who are not yet competent. If this opinion is related to the performance of teachers at SMP Negeri 1 Sungai Lilin which has shown well with the respondent's answer indicator $67.5 \%$ in the high category and $35.5 \%$ in the moderate category, it means that the leadership function of the principal has been running according to his main duties and duties and teachers who have already competent.

The magnitude of the effect simultaneously, which only reached $53.5 \%$ in this study, can be an indication that the high performance of teachers at SMP Negeri 1 Sungai Lilin is influenced by other factors, besides the significant competence of teachers. As revealed by Pianda (2018), factors that influence teacher performance include teacher education level, teaching supervision, upgrading programs, conducive climate, facilities and infrastructure, teachers' physical and mental conditions, principal leadership style, welfare assurance, and abilities managerial principal.

\section{Conclusion}

There is no influence of the principal's leadership on teacher performance at SMP Negeri 1 Sungai Lilin based on the t-count of 1.915 which is smaller than the t-table 2.024 while the correlation of the variables is in the low category with an $\mathrm{R}$ value of 0.297 , the amount of influence based on the R Square value is only $8.8 \%$ the remaining $91,2 \%$ is influenced by other variables and depicted in the linear regression equation is $\mathrm{Y}=1.547+0.330 \mathrm{X}_{1}$. There is an effect of teacher's competence on teacher's performance at SMP Negeri 1 Sungai Lilin with a t-count value of 6,561 greater than t-table 2,024, while the correlation of variables is in the strong category with an $\mathrm{R}$ value of 0.729 , the amount of influence is based on the $\mathrm{R}$ Square value of $53.1 \%$ while the remaining $46.9 \%$ is influenced by other variables and described in the linear regression equation is $\mathrm{Y}=0.595+914 \mathrm{X}_{2}$. Simultaneously there is the influence of principal's leadership and teacher's competence on teacher's performance at SMP Negeri 1 Sungai Lilin based on the value of F-count 21.261> F-table 3.24, the correlation of the variables is in the strong category with an $\mathrm{R}$ value of 0.731 and the amount of influence is based on the $\mathrm{R}$ square value of $53.5 \%$ as for the rest $46.5 \%$ is influenced by other factors which are not the variables of this study and is described in the multiple regression equation as $\mathrm{Y}=0.493+0.071 \mathrm{X}_{1}+0.887 \mathrm{X}_{2}$. 


\section{E. Acknowledgement}

We would like to express our special thanks and gratitude to Principal SMP Negeri 1 Sungai Lilin, Rector Universitas PGRI Palembang, Director of Graduate Program Universitas PGRI Palembang and Study Program of Educational Management Universitas PGRI Palembang who gave us the support to do this wonderful project. This project was funded independent. Secondly, we would also like to thank our friends in Educational Management who helped us a lot in finalizing this project within the limited time frame.

\section{References}

Andang. (2014). Manajemen dan Kepemimpinan Kepala Sekolah [Principal Management and Leadership]. Jogjakarta: ArRuzz Media.

Andriani, S., Kesumawati, N., \& Kristiawan, M. (2018). The Influence of the Transformational Leadership and Work Motivation on Teachers Performance. International Journal of Scientific \& Technology Research, 7(7).

Daryanto. (2013). Inovasi Pembelajaran Efektif [Effective Learning Innovations]. Bandung: Yrma Widya

Fathurrochman, I., Budiman, D. A., Alamsyahril, \& Kristiawan, M. (2019). Revitalization Management of Islamic Boarding School Preventing The Radicalism. Restaurant Business, (10), 495-505.

Irmayani, H., Wardiah, D., \& Kristiawan, M. (2018). The Strategy of SD Pusri In Improving Educational Quality. International Journal of Scientific \& Technology Research, 7(7).

Kartini, D., Kristiawan, M., \& Fitria, H. (2020). The Influence of Principal's Leadership, Academic Supervision, and Professional Competence toward Teachers' Performance. International Journal of Progressive Sciences and Technologies (IJPSAT), 20(1), 156-164.

Kristiawan, M. (2015). A Model of Educational Character in High School Al-Istiqamah Simpang Empat, West Pasaman, West Sumatera. Research Journal of Education, 1(2), 15-20.

Kristiawan, M., Nizarani., \& Syamsidar. (2019). Role of School on Forming Character of ZGeneration Through Entrepreneurial Skills. International Journal of Scientific \& Technology Research, 8(10).

Khasanah, U., Kristiawan, M., \& Tobari. (2019). The Implementation of Principals' Academic Supervision In Improving Teachers' Professionalism in the State Primary Schools. International Journal of Scientific \& Technology Research, 8(8).

Law Number 20 of 2003

Law Number 14 of 2005 
Volume 1 (2) 2020

E-ISSN: 2723-6919

Lian, B., Kristiawan, M., Primasari, D. A. G., \& Prasetyo, M. A. M. (2020). Teachers' Model In Building Students' Character. Journal of Critical Reviews, 7(14), 927-932.

Mataputun, A. (2020). Implementasi Tugas Komite Sekolah Dalam Meningkatkan Mutu Pelayanan Pendidikan Di Sma Negeri 2 Kabupaten Sarmi [Implementation of School Committee Duties in Improving the Quality of Education Services at Senior High School 2, Sarmi Regency]. NOKEN: Jurnal Pengelolaan Pendidikan https://ejournal.uncen.ac.id/index.php/NOKEN/article/view/1280

Pianda, D. (2018). Kinerja Guru: Kompetensi Guru, Motivasi Kerja dan Kepemimpinan [Teacher Performance: Teacher Competence, Work Motivation and Leadership]. https://books.google.co.id/books/about/Kinerja_guru_kompetensi_guru_motivasi_ke. html?id=d7VsDwAAQBAJ\&redir_esc=y

Ridwan., \& Karna. (2018). The Effect of Principal Leadership, Teacher Competence, and Teacher Compensation on Teacher Performance in SMP Pertiwi

Salwa., Kristiawan, M., \& Lian, B. (2019). The Effect of Academic Qualification, Work Experience and Work Motivation towards Primary School Principal Performance. International Journal of Scientific \& Technology Research, 8(8).

Sayer, I. M., Kristiawan, M., \& Agustina, M. (2018). Fairy Tale as a Medium for Children's Character Cooperation Building. Al-Ta lim Journal, 25(2), 108-116.

Tobari., Kristiawan, M., \& Asvio, N. (2018). The Strategy of Headmaster on Upgrading Educational Quality In Asean Economic Community (AEC) Era. International Journal of Scientific \& Technology Research, 7(4).

Zubaidah. (2016). The Influence of Principal Leadership and Teacher Competence on Teacher Motivation and Its Implementation on Teacher Performance at SMP Negeri Palembang City 